University of Nebraska - Lincoln

DigitalCommons@University of Nebraska - Lincoln

1998

Reverting Conservation Reserve Program Lands to Wheat and Livestock Production: Effects on Ground Beetle (Coleoptera: Carabidae) Assemblages

B. Wade French

Plant Science Research Laboratory, USDA-ARS, Wade.French@ars.usda.gov

Norman C. Elliott

Plant Science Research Laboratory, USDA-ARS

Richard C. Berberet

Plant Science Research Laboratory, USDA-ARS

Follow this and additional works at: https://digitalcommons.unl.edu/entomologyother

Part of the Entomology Commons

French, B. Wade; Elliott, Norman C.; and Berberet, Richard C., "Reverting Conservation Reserve Program Lands to Wheat and Livestock Production: Effects on Ground Beetle (Coleoptera: Carabidae) Assemblages" (1998). Entomology Papers from Other Sources. 102.

https://digitalcommons.unl.edu/entomologyother/102

This Article is brought to you for free and open access by the Entomology Collections, Miscellaneous at DigitalCommons@University of Nebraska - Lincoln. It has been accepted for inclusion in Entomology Papers from Other Sources by an authorized administrator of DigitalCommons@University of Nebraska - Lincoln. 


\title{
Reverting Conservation Reserve Program Lands to Wheat and Livestock Production: Effects on Ground Beetle (Coleoptera: Carabidae) Assemblages
}

\author{
B. WADE FRENCH, NORMAN C. ELLIOTT, AND RICHARD C. BERBERET ${ }^{l}$
}

Plant Science Research Laboratory, USDA-ARS, SPA, 1301 N. Western, Stillwater, OK 74075

Environ. Entomol. 27(6): 1323-1335 (1998)

\begin{abstract}
Highly erodible lands enrolled in the Conservation Reserve Program soon will revert to agricultural production. This study was designed to determine the effects of reversion of Conservation Reserve Program lands to wheat and livestock production on ground beetle assemblages. Reversion strategies included no reversion of Conservation Reserve Program grass (unmanaged bluestem), simulated grazing of Conservation Reserve Program grass (managed bluestem), minimum-tillage practices for wheat production, and no-tillage practices for wheat production. A randomized block experimental design was established with 4 replicates. More ground beetles were captured in pitfall traps in 1995 than in 1996, and abundances within years differed among reversion strategies. Of the 73 ground beetle species collected, 9 species accounted for $61.7 \%$ of total abundance. Abundances of these 9 species differed with respect to reversion strategy. Species diversity and evenness differed among the reversion strategies in 1995, but only evenness differed in 1996 . Canonical correspondence analysis showed that annual and monthly variation were the predominant factors in separating ground beetle assemblages. Lack of rainfall may have accounted for a large portion of differences in abundances between years. A partial canonical correspondence analysis showed that simulated grazing and no-tillage wheat were the predominant reversion strategies in separating ground beetle assemblages. These treatments represent disturbance levels intermediate to unmanaged bluestem and minimum-tillage wheat.
\end{abstract}

KEY WORDS Carabidae, insect predators, biological control, Conservation Reserve Program, tillage, wheat

THE Loss of topsoil due to water and wind erosion is a major concern worldwide (Pimentel et al. 1995). The U.S. government established the Conservation Reserve Program in the 1985 Food Security Act to reduce the amount of topsoil lost from highly erodible lands (USDA 1996). Farmers were compensated monetarily for enrolling their lands in this program. In Oklahoma, 0.5 million hectares are enrolled as Conservation Reserve Program lands (USDA 1996). Anticipated changes in federal farm programs may significantly reduce the acreage in the Conservation Reserve Program and bring this fragile land back into agricultural production. Much of this land in Oklahoma will revert to wheat, Triticum aestivum $\mathrm{L}$., and pasture for livestock production. With reversion to agricultural production, farmers will employ different strategies to limit loss of topsoil and regulate pests while maximizing wheat and livestock production.

Ground beetles are generalist predators of agricultural pests and play an important role in controlling pests in many agroecosystems (Sunderland and Vick-

\footnotetext{
${ }^{1}$ Department of Entomology, Oklahoma State University, Stillwater, OK 74078.

This article reports the results of research only. Mention of a proprietary product does not consitute an endorsement or a recom-
} mendation by the USDA for its use. erman 1980, Scheller 1984, Floate et al. 1990, Winder 1990, Ekbom et al. 1992, Holopainen and Helenius 1992, Sunderland et al. 1995). If Conservation Reserve Program lands revert to pasture for grazing livestock, an increased level of disturbance to the vegetation and soil may occur and may significantly alter assemblages of ground beetles. If Conservation Reserve Program lands revert to wheat production, complete and abrupt changes in the vegetation and ground cover will occur, and this too may alter assemblages of ground beetles.

With the reversion to wheat production, tillage practices will dictate the degree of disturbance to the soil and vegetation. Deep tillage of the soil, as is done with conventional methods, removes $\geq 70 \%$ of all vegetative residue from the ground surface, and consequently disrupts the life cycles of many species. Conservation tillage practices leave $\geq 30 \%$ plant residue on the soil surface after planting (Gebhardt et al. 1985). One conservation practice is no tillage, which leaves $\geq 60 \%$ of plant residue on the soil surface after planting. Stinner and House (1990) reviewed the effects of conservation tillage practices on various groups of arthropods and other invertebrates.

The effects of conventional and conservation tillage practices on species diversity and relative abundances 
of ground beetle species have been studied widely (Tyler and Ellis 1979, Dritschilo and Wanner 1980, Barney and Pass 1986, Weiss et al. 1990, Laub and Luna 1992, Tonhasca 1993, Cárcamo 1995, Cárcamo et al. 1995). Although ground beetle diversity sometimes increases with decreased tillage (Stinner and House 1990), other indications are that diversity and abundance are not changed (Barney and Pass 1986). In the northern Great Plains, ground beetle diversity and abundance were altered more by some crop rotations than by tillage practices (Weiss et al. 1990). In central Alberta, ground beetle abundance was higher under conventional tillage than under conservation tillage (Cárcamo 1995).

The effects of grazing on species diversity and relative abundances of ground beetles has also shown mixed results (Rushton et al. 1986, Luff and Rushton 1988, Morrill 1992, Dennis et al. 1997). In Georgia, ground beetle abundance was not different among grazed and ungrazed grasslands (Morrill 1992). In England, managed grasslands that included grazing had lower ground beetle diversity than managed grasslands that did not include grazing (Luff and Rushton 1988). Dennis et al. (1997) found that some species of ground beetles were captured in greater numbers in ungrazed grasslands than in grazed grasslands. In contrast, Dennis et al. (1997) also found that the abundance of other species of ground beetles was higher in grazed grasslands than in ungrazed grasslands.

Farmers may encounter new pest problems with elimination of the Conservation Reserve Program and implementation of crop and livestock production. As generalist predators, ground beetles may play an important role in maximizing agricultural production (Potts and Vickerman 1974). Our objectives were to determine the following: (1) the temporal structure of spring assemblages of ground beetles, (2) the effects on ground beetle assemblages from converting Conservation Reserve Program lands to wheat production using minimum and no-tillage practices, and (3) the effects on ground beetle assemblages from converting Conservation Reserve Program lands to grazing lands for livestock production.

\section{Materials and Methods}

Study Area and Pitfall Trap Design. This study was conducted in 1995 and 1996 in Beaver County of western Oklahoma on 18 ha of Conservation Reserve Program land. The 18-ha study site was part of a 115-ha pasture. This pasture entered the Conservation Reserve Program in 1989 and was planted with Old World Bluestem, Bothriochloa bladhii (Retzius). This is an imported bunch grass that is commonly planted in the region for erosion control. The land will revert to agricultural production in 1999. Before enrollment in Conservation Reserve Program, this land was routinely planted with winter wheat. Beaver County is part of the short grass prairie region of the southern Great Plains (Kaul 1986). The soil type at the study site is Dalhart fine sandy loam (taxonomic class: fineloamy, mixed, mesic Aridic Haplustalfs) (USDA
1962). Although preceding the full 10 -yr enrollment period, this study represents the 1st and 2nd yr of reversion from Conservation Reserve Program to wheat or pasture.

A randomized complete block experimental design was used with 4 treatments and 4 replications: unmanaged old World Bluestem, managed old World Bluestem, minimum-tillage wheat, and no-tillage wheat. Each block was 92 by $230 \mathrm{~m}$. Each plot within a block was 92 by $46 \mathrm{~m}$. Because this is the initial attempt at reverting Conservation Reserve Program lands to wheat production in this region, several techniques were used to eliminate Old World Bluestem from the wheat plots. Due to the sensitivity of this land to erosion, the Old World Bluestem could not be plowed into the soil. Farmers in this region will employ similar techniques to revert their Conservation Reserve Program lands to wheat and livestock production. During the 1st yr of reversion (1994-1995), the Old World Bluestem was burned in May 1994 to remove previous growth. In July 1994, tillage was accomplished by undercutting the Old World Bluestem with a 91-cm V-blade sweep. This reduced-tillage method contrasts with the no-tillage strategy where no disturbance to the soil occurred except for planting the wheat. Herbicide (1.1 $\mathrm{kg}^{-1}$ [AI]/ha glyphosate) was sprayed to kill the Old World Bluestem in the no-tillage and minimum-tillage wheat plots in August 1994 and June 1995. Wheat was planted, using a no-till drill, in the no-tillage and minimum-tillage wheat plots in September 1994. For the 1995-1996 season, sweep tillage was performed on minimum-tillage wheat in June, August, and October. The repeated tillage was in response to regrowth of Old World Bluestem and weeds. Wheat was planted in the no-tillage wheat and minimum-tillage wheat plots in October 1995. Along with drilling of wheat, $110.7 \mathrm{~kg}^{-1}$ (AI) / ha of 18-46-0 fertilizer was placed in the seed rows. In addition, 66.3 $\mathrm{kg}^{-1}$ (AI)/ha of urea-N was applied to all plots in March. The managed bluestem plots were mowed periodically to simulate grazing effects by cattle. The mowed grass was not manually removed from the plots. In contrast, the unmanaged bluestem plots acted as controls and were not mowed.

Eight pitfall traps were established in each plot to capture ground beetles (Fig. 1). Trap design followed that of Morrill (1975). These traps consisted of a 455-ml Solo (Concept Communications, Burr Ridge, IL) cup with a 145-mm i.d., a Solo Cozy Cup funnel, and an inner 148-ml Solo cup partially filled with ethylene glycol as a preservative. Galvanized sheet metal strips ( 24 gauge, 14 by $122 \mathrm{~cm}$ ) were used as guides to facilitate the capture of the beetles by channeling their movement into the traps (Durkis and Reeves 1982). We placed these traps in the center of each plot at equal distances. We positioned the guides in alternating directions to facilitate the capture of ground beetles walking in different directions. Pitfall traps were established on 9 March 1995 and 27 March 1996 and checked weekly through 24 June 1995 and 14 June 1996. 


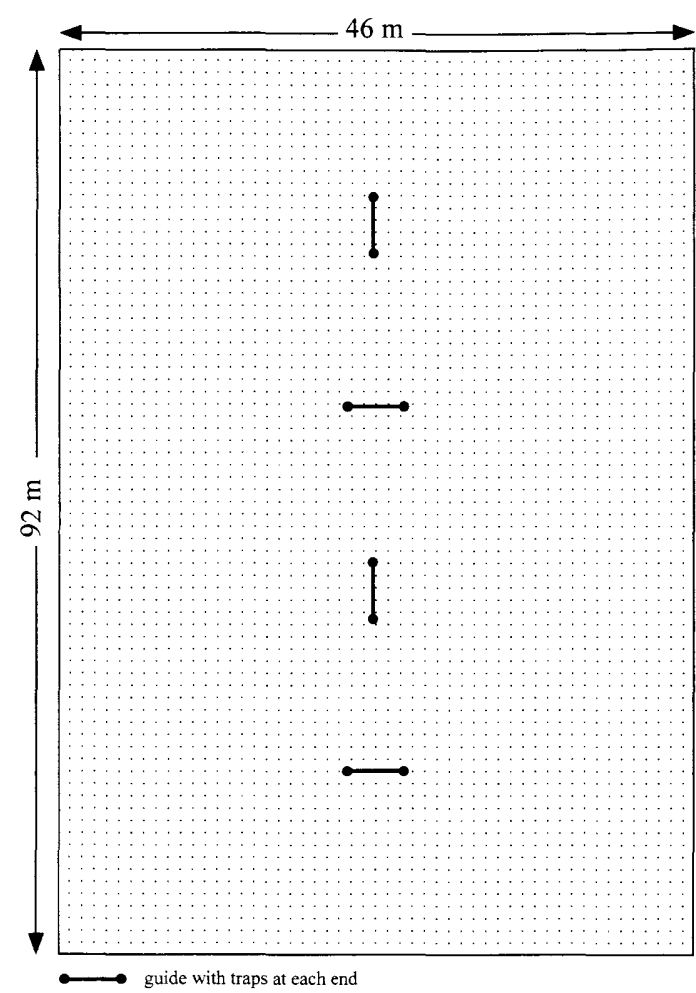

Fig. 1. Arrangement of pitfall traps and guides within each plot.

Although pitfall traps are the most widely used devices for capturing ground beetles and other epigeal arthropods, they are not without their flaws. Trap efficiency in capturing ground beetles, the proportion captured to total possible captures, is affected by trap design, individual behavior of species, and type of habitats in which the traps are placed (Greenslade 1964, Halsall and Wratten 1988, Morrill et al. 1990, Spence and Niemelä 1994). Some habitats restrict the movement of ground beetles, thus 2 habitats may have the same density of ground beetles, but one may be more conducive to beetle movement, and hence catch-ability (Frampton et al. 1995, Mauremooto et al. 1995). The numbers of beetles captured from these 2 habitats could wrongly indicate that they differed in beetle density. So data collected from pitfall traps must be examined with caution. However, using pitfall traps to capture ground beetles over their whole activity period (several weeks or months) does provide reliable estimates of their population sizes (Baars 1979).

Simpson's diversity index (D) and equatability in$\operatorname{dex}(\mathrm{E})$ were used to evaluate species diversity and species evenness (Begon et al. 1990). Species richness is the number of species collected, with no consideration of the abundance of species; rare and common species are rated equally. Species diversity considers relative species abundance in addition to the number of species, and therefore accounts for differences in species abundance. The evenness index accounts for variation in relative abundances, with values ranging from 0 (high variability in numbers among species) to 1 (no variability in numbers among species).

Data Analysis. The total counts and relative abundances of all ground beetles were analyzed with canonical correspondence analysis of CANOCO (ter Braak 1987) to compare assemblages among treatments. Canonical correspondence analysis is a robust method for ordinating data obtained from pitfall traps (Palmer 1993) and is commonly used for direct gradient analysis that relates species' abundances to environmental variables. Species are separated and associated along these environmental gradients. The data were grouped by month to account for temporal changes in ground beetle assemblages. We used the following 10 environmental variables: 1995 season, 1996 season, March, April, May, June, unmanaged bluestem, managed bluestem, no-tillage wheat, and minimum-tillage wheat. These environmental variables were used as dummy variables $(1 / 0)$. In a canonical correspondence analysis, species that are strongly associated with a particular year, a particular month, or a particular treatment will ordinate along the respective environmental axis.

We used a partial canonical correspondence analysis to focus on the effects of the 4 treatments on ground beetle assemblages (transformed to squareroot of relative abundance) by factoring out the covariables years and months. Analysis of variance (ANOVA) for a randomized complete block design was used to determine differences in mean ground beetle abundance, species richness, species diversity, and species evenness among treatments. Because the same 18 ha was used in 1995 and 1996, the data were analyzed separately to avoid pseudoreplication of years (Hurlbert 1984, Dennis et al. 1997). Species of ground beetles representing $1 \%$ or less of total abundance were considered rare. The occurrences of these rare species are reported with the community parameters. No statistical tests were performed on the rare species, except that they were included in the canonical correspondence analyses (see Appendix 1).

\section{Results}

Species Data. Nearly 3,000 ground beetles, representing 73 species, were captured over all treatments in 1995 and 1996 (Table 1). The total number of ground beetles captured in 1995 was much higher than the total number captured in 1996. In both years, capture of ground beetles peaked in May and June (Fig. 2). In 1995, total abundance of all species differed significantly among treatments $(F=38.60$; $\mathrm{df}=3,9$; $P<0.01)$. All treatments differed significantly in number of beetles captured (Table 2). More beetles were captured in managed bluestem, no-tillage wheat, minimum-tillage wheat, and then unmanaged bluestem. Five of 60 species, Amara cupreolata Putzeys, Anisodactylus dulcicollis LaFerté, A. rusticus Say, Galerita janus $\mathbf{F}$., and Pasimachus elongatus LeConte accounted for $63 \%$ of all individuals captured in 1995 (Table 1). The abundance of 3 species varied among treatments: 
Table 1. The number and percentage of ground beetles captured in unmanaged Old World bluestem, managed Old World bluestem, no-tillage wheat, and minimum-tillage wheat in 1995 and 1996

\begin{tabular}{|c|c|c|c|c|c|c|}
\hline Species & $\begin{array}{l}\text { Unmanaged } \\
\text { bluestem }\end{array}$ & $\begin{array}{l}\text { Managed } \\
\text { bluestem }\end{array}$ & $\begin{array}{l}\text { No-tillage } \\
\text { wheat }\end{array}$ & $\begin{array}{c}\text { Min.-tillage } \\
\text { wheat }\end{array}$ & Total & $\%$ \\
\hline \multicolumn{7}{|c|}{1995} \\
\hline Anisodactylus dulcicollis & 27 & 284 & 51 & 43 & 405 & 20.3 \\
\hline Galerita janus & 25 & 16 & 238 & 22 & 301 & 15.1 \\
\hline Pasimachus elongatus & 27 & 123 & 70 & 50 & 270 & 13.5 \\
\hline Anisodactylus rusticus & 22 & 51 & 42 & 69 & 184 & 9.2 \\
\hline Amara cupreolata & 15 & 66 & 14 & 10 & 105 & 5.3 \\
\hline Other Species & 105 & 291 & 188 & 148 & 732 & 36.6 \\
\hline Total & 221 & 831 & 603 & 342 & 1,997 & 100.0 \\
\hline \multicolumn{7}{|c|}{1996} \\
\hline Pasimachus elongatus & 23 & 29 & 26 & 17 & 95 & 11.0 \\
\hline Cymindis laticollis & 19 & 17 & 49 & 9 & 94 & 10.9 \\
\hline Anisodactylus rusticus & 5 & 20 & 29 & 32 & 86 & 9.9 \\
\hline Cratacanthus dubius & 2 & 14 & 19 & 49 & 84 & 9.7 \\
\hline Selenophorus planipennis & 5 & 29 & 29 & 20 & 83 & 9.6 \\
\hline Harpalus desertus & 4 & 22 & 17 & 21 & 64 & 7.4 \\
\hline Other Species & 92 & 85 & 101 & 81 & 359 & 41.5 \\
\hline Total & 150 & 216 & 270 & 229 & 865 & 100.0 \\
\hline
\end{tabular}

A. dulcicollis $(F=23.83 ; \mathrm{df}=3,9 ; P<0.01)$, G. janus $(F=31.55 ; \mathrm{df}=3,9 ; P<0.01)$, and $P$. elongatus $(F=$ $7.12 ; \mathrm{df}=3,9 ; P<0.01)$. Significantly more A. dulcicollis were captured in managed bluestem. G. janus was captured significantly more often in the no-tillage wheat. $P$. elongatus was captured significantly more often in managed bluestem and no-tillage wheat (Table 2). There were no treatment effects for $A$. cupreolata and $A$. rusticus.

In 1996, total abundance of all species differed significantly among treatments $(F=4.95$; $\mathrm{df}=3,9 ; P<$
$0.05)$. This difference was due to the low numbers captured in unmanaged bluestem (Table 2). Six of 51 species, A. rusticus, Cratacanthus dubius Palisot de Beauvois, Cymindis laticollis Say, Harpalus desertus LeConte, P. elongatus, and Selenophorus planipennis LeConte, accounted for $59 \%$ of all individuals captured in 1996 (Table 1). Of these 6 species, significant differences among the treatments in numbers captured were found for 2 species: A. rusticus ( $F=12.93$; $\mathrm{df}=3,9 ; P<0.01)$ and $C$. dubius $(F=12.51 ; \mathrm{df}=3$, $9 ; P<0.01)$. There was a marginal treatment effect for

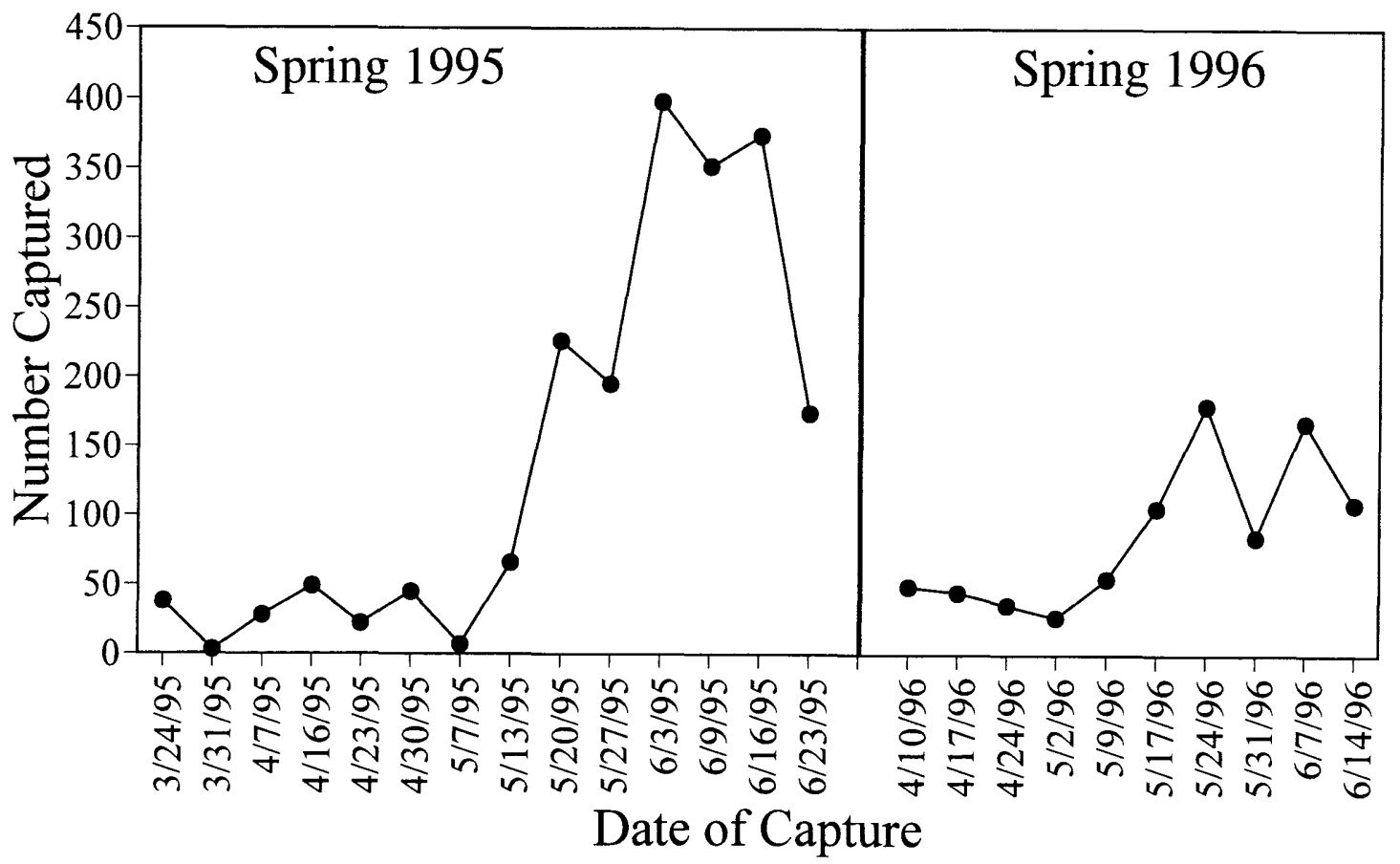

Fig. 2. Number of ground beetles captured in 1995 and 1996, by sampling date. 
Table 2. Mean number $( \pm S E M)$ of beetles captured for years and species with respect to reversion strategies (See text for explanation of reversion strategies.)

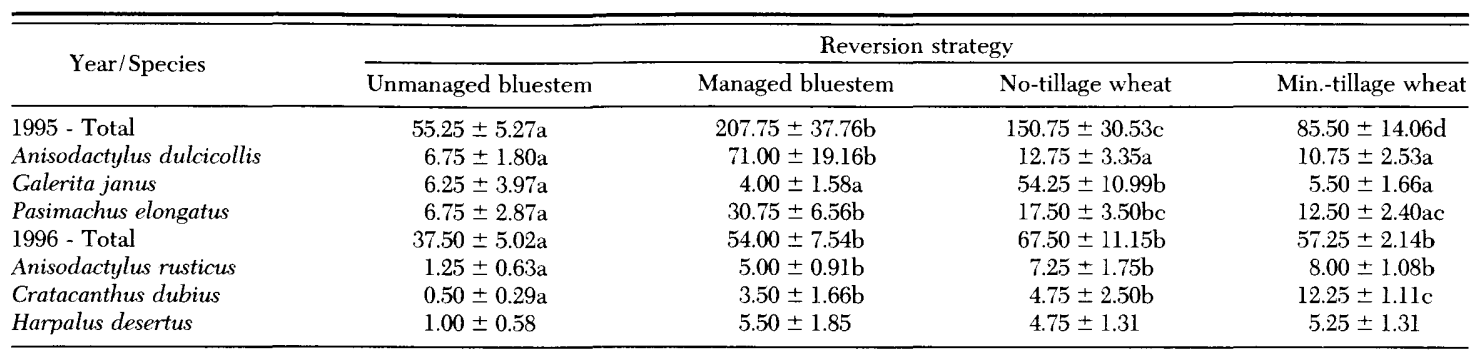

Values within rows with different letters are significantly different (Fisher protected LSD tests).

H. desertus $(F=3.67 ; \mathrm{df}=3,9 ; P=0.0565)$, which was captured in low numbers in unmanaged bluestem. All 3 of these species were captured in low numbers in unmanaged bluestem, and C. dubius was captured significantly more often in minimum-tillage wheat (Table 2).

With respect to community parameters, there were no significant differences in species richness among treatments in 1995 and 1996 (Table 3). Species diversity differed significantly among treatments in 1995 $(F=3.94 ; \mathrm{df}=3,9 ; P<0.05)$, but not in 1996. In 1995, species diversity was highest in unmanaged bluestem and lowest in no-tillage wheat (Table 3). Species evenness differed significantly among treatments in $1995(F=10.43 ; \mathrm{df}=3,9 ; P=0.01)$ and $1996(F=4.07$; $\mathrm{df}=3,9 ; P<0.05)$. In 1995, species evenness was greater in unmanaged bluestem and minimum-tillage wheat than in managed bluestem and no-tillage wheat, whereas in 1996, it was greater in the bluestem treatments than in the wheat treatments (Table 3). Of the 60 species captured in 1995, 44 were considered rare and represented $11.4 \%$ of total abundance. These species were captured more frequently in managed bluestem and no-tillage wheat than in minimum-tillage wheat and unmanaged bluestem (Table 3). Of the 51 species captured in 1996, 29 were considered rare and represented $11.6 \%$ of total abundance. These species were captured more frequently in unmanaged bluestem and no-tillage wheat than in minimum-tillage wheat and managed bluestem (Table 3).
Multivariate Analysis. To determine differences in species compositions between 1995 and 1996, year was included in the canonical correspondence analysis as an environmental dummy variable. The eigenvalues for canonical correspondence analysis axes 1 through 4 were $0.321,0.247,0.111$, and 0.094 , respectively. These values represent the amount of variation in species scores explained by their respective axis, and therefore by the environmental variables (ter Braak 1987). The cumulative percentage variance of speciesenvironment relationship explained by the 4 axes was 78.6. Axis 1 separated ground beetle assemblages by year, and axis 2 separated ground beetle assemblages by month (Fig 3.). Environmental variables are indicated by arrows and species scores are indicated as abbreviated names (Appendix 1). Species that are associated with environmental variables are positioned close to the respective arrow. Ground beetles associated with 1995 have negative scores on axis 1 , while ground beetles associated with 1996 have positive scores on this axis (Fig. 3). Note that the dominant ground beetles for 1995 and 1996 separated along axis 1 , and that the 2 species dominant in both years, $P$. elongatus and A. rusticus, ordinated near the axis origin. Ground beetles associated with early spring (March and April) had positive scores on axis 2, whereas those associated with late spring (May and June) have negative scores on this axis. Ground beetles scores positioned near the origin were not strongly associated with either of these temporal gradients. To

Table 3. Community parameters (means \pm SEM) and numbers of rare species for ground beetles captured in unmanaged Old World bluestem, managed Old World bluestem, no-tillage wheat, and minimum-tillage wheat plots

\begin{tabular}{|c|c|c|c|c|}
\hline Community parameter & Unmanaged bluestem & Managed bluestem & No-tillage wheat & Min.-tillage wheat \\
\hline \multicolumn{5}{|c|}{1995} \\
\hline Species richness & $19.50 \pm 2.10$ & $25.50 \pm 2.25$ & $23.75 \pm 2.98$ & $20.00 \pm 1.87$ \\
\hline Simpson's diversity index & $9.74 \pm 1.51 \mathrm{a}$ & $6.01 \pm 1.04 \mathrm{bc}$ & $5.37 \pm 0.65 b$ & $8.75 \pm 0.58 \mathrm{ac}$ \\
\hline Simpson's evenness index & $0.5 \mathrm{l} \pm 0.08 \mathrm{a}$ & $0.23 \pm 0.03 b$ & $0.24 \pm 0.03 \mathrm{~b}$ & $0.44 \pm 0.03 \mathrm{a}$ \\
\hline Rare species occurrences & 39 & 80 & 68 & 42 \\
\hline \multicolumn{5}{|c|}{1996} \\
\hline Species richness & $19.00 \pm 1.47$ & $19.25 \pm 0.95$ & $20.25 \pm 1.03$ & $17.50 \pm 0.65$ \\
\hline Simpson's diversity index & $11.28 \pm 1.21$ & $11.43 \pm 1.01$ & $9.42 \pm 1.32$ & $8.24 \pm 0.62$ \\
\hline Simpson's evenness index & $0.60 \pm 0.07 a$ & $0.59 \pm 0.04 \mathrm{a}$ & $0.46 \pm 0.05 b$ & $0.47 \pm 0.03 b$ \\
\hline Rare species occurrences & 31 & 22 & 30 & 17 \\
\hline
\end{tabular}

Values within rows with different letters are significantly different (Fisher protected LSD tests). 


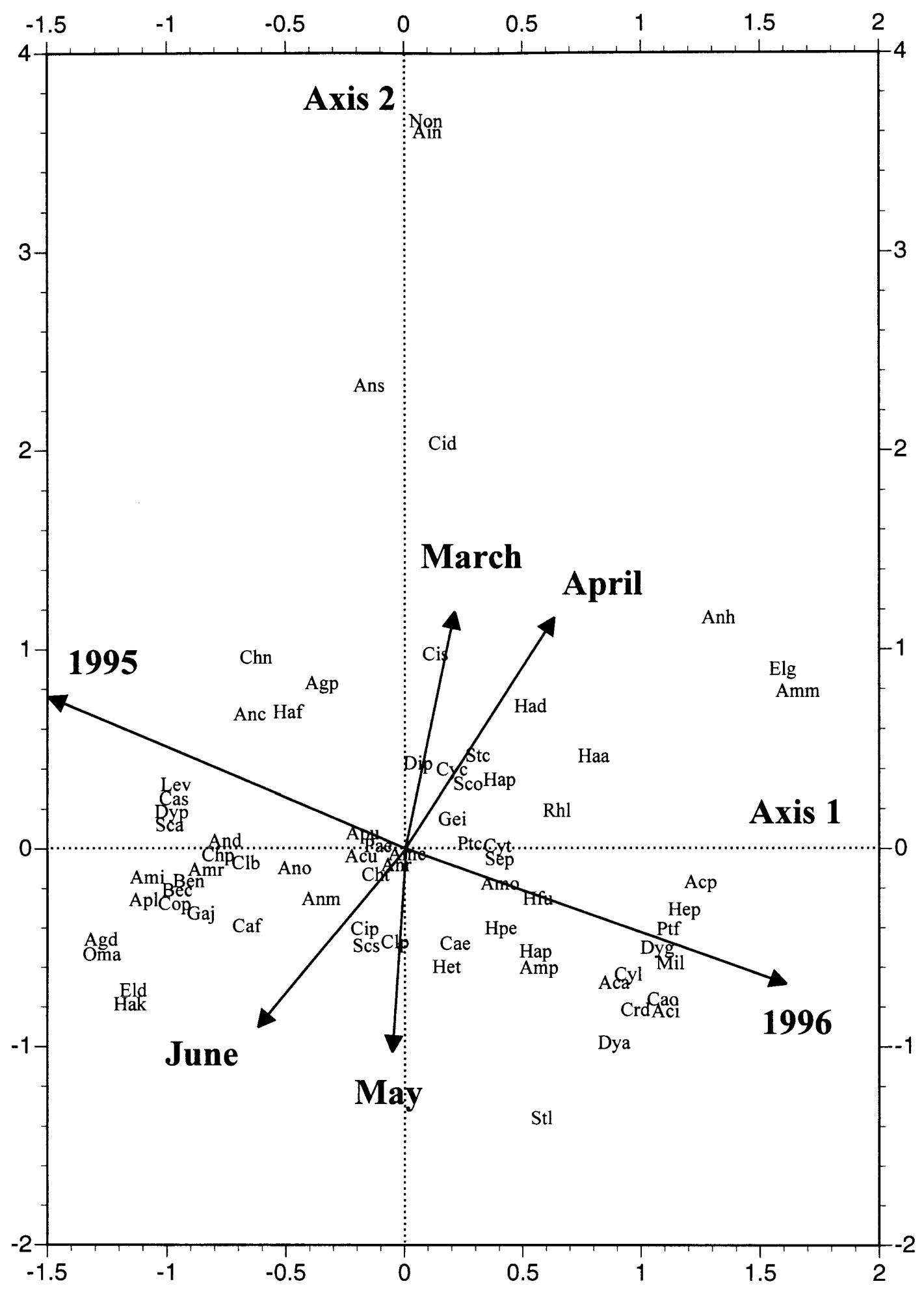

Fig. 3. Biplot of species scores and environmental variables obtained from canonical correspondence analysis. Species names are abbreviated (see Appendix 1) and environmental variables are indicated by arrows. Only the most important environmental variables are indicated. 
determine the robustness of the ordination of ground beetle assemblages, a Monte Carlo randomization test was performed (ter Braak 1987). Based on this test, the observed patterns of ground beetle abundances and environmental variables differed significantly from random (Monte Carlo, $F$ ratio $=1.67, P<0.01$ ), indicating that the ordination was a valid representation of patterns in the ground beetle assemblages.

To describe the effects of type of treatments on species composition, the $2 \mathrm{yr}$ and 4 mo were factored out as covariables. The eigenvalues for axes 1 through 3 were $0.100,0.079$, and 0.069 . Again, these values measured the amount of variation in species scores explained by their respective axes, with axis 1 explaining more variation in species scores than the other axes (Fig. 4a). These eigenvalues were much smaller than the previous eigenvalues because of the strong annual and monthly influences on ground beetle assemblages. Together, these 3 axes explained $100 \%$ of the variation in species scores remaining after partialling out year and seasonal effects. The distribution of ground beetle species associated with unmanaged bluestem, managed bluestem, no-tillage wheat, and minimum-tillage wheat separated along axes 1 and 2 (Fig. 4a). The lst axis separated species trapped most often in wheat and old World Bluestem. Species plotted near the origin were equally distributed among treatments, while those occurring near the ends of the axes preferred a particular treatment. Ground beetles preferring wheat appear in the positive space of axis 1, whereas ground beetles preferring Old World Bluestem appear in the negative space of axis 1 . Ground beetles associated with unmanaged bluestem and managed bluestem were separated along axis 2. Ground beetles preferring unmanaged bluestem appear in the positive space of axis 2, whereas ground beetles preferring managed bluestem appear in the negative space of axis 2. Axis 2 partially separated ground beetles with respect to wheat management. Minimum-tillage wheat ordinated in negative space of axis 2 , whereas no-tillage wheat slightly ordinated in positive space of axis 2 . When plotted on axis 1 and axis 3 , however, minimumtillage wheat and its associated ground beetles separated strongly along the positive space of axis 3 (Fig. 4b).

\section{Discussion}

It is typical for a few ground beetle species to dominate an assemblage in relative abundance (Thiele $1977)$. In this study, 9 species $(12.3 \%)$ of the 73 species captured accounted for $61.7 \%$ of all ground beetles captured. Other studies also have found that a few species dominate the ground beetle fauna in agroecosystems (Kirk 1971, Barney and Pass 1986, Laub and Luna 1992, Tonhasca 1993, Cárcamo 1995). The number of ground beetles captured in 1995 more than doubled the number captured in 1996. This difference may be because of the variation in rainfall amount between the $2 \mathrm{yr}$. Total rainfall during the 1994-1995 wheat-growing season was $80 \mathrm{~mm}$ above normal amounts (Fig. 5a). In contrast, total rainfall during
1995-1996 wheat-growing season was $65 \mathrm{~mm}$ below normal amounts (Fig. 5a). Even though this is a relatively dry region of the Great Plains and ground beetles probably are adapted to the precipitation levels, this drought may have caused the desiccation of many overwintering ground beetles (Allen 1979). The drought possibly affected $A$. dulcicollis population numbers quite drastically. In 1995, 480 individuals were captured, whereas only 3 individuals were captured in 1996. We found similar differences for $G$. janus (301 and 4), but less drastic differences for some other species.

Spring months (March-June) are an active period for many species of ground beetles. Site scores classified by month represented a temporal gradient. Activity peaked in May and June of both years. Nightly temperatures are higher in these months relative to March and April (Fig. 5b). Because most ground beetles are nocturnal predators and their activity is influenced by temperature (Thiele 1977), this increase in nightly temperatures may explain in part this peak in numbers captured. In South Dakota, activity periods for ground beetles peaked in August and September over a sampling period from June to November (Kirk 1971). Although, Kirk did not present any temperature data, presumably nightly temperatures correlated with ground beetle activity. Many of the same species captured by Kirk were captured in this study. For example, $P$. elongatus was 1 of the most abundant species in Kirk's study and in this study.

Ground beetles differed in their response to tillage practices for converting Conservation Reserve Program lands to wheat production. More ground beetles were captured in no-tillage wheat (873) than in minimum-tillage wheat (571) in both years. Among the most abundant species captured, only $G$. janus showed a strong preference for no-tillage wheat over minimum-tillage wheat. This species is common in many habitats in Oklahoma (French 1998). Some other species tended to prefer no-tillage wheat over minimumtillage wheat. These species included $A$. cupreolata, $A$. dulcicollis, $C$. laticollis, and P. elongatus. In contrast, A. rusticus, C. dubius, $H$. desertus, and S. planipennis tended to prefer minimum-tillage wheat over no-tillage wheat. The factors determining habitat preference by these species are unknown, but may be due to microclimatic differences between no-tillage wheat and minimum-tillage wheat. Some species, such as $A$. cupreolata prefer mesic habitats over zeric habitats (Epstein and Kulman 1990). The soil and vegetation were less disturbed under no-tillage than under minimum-tillage, and perhaps this caused a higher moisture content in no-tillage wheat. However, P. elongatus seemingly prefers zeric habitats over mesic habitats (Epstein and Kulman 1990), yet it too preferred notillage wheat over minimum-tillage wheat. Another possibility is that no-tillage wheat had more prey available than minimum tillage wheat. It is known that some species of ground beetles will aggregate in areas with high population densities of cereal aphids (Bryan and Wratten (1984). 


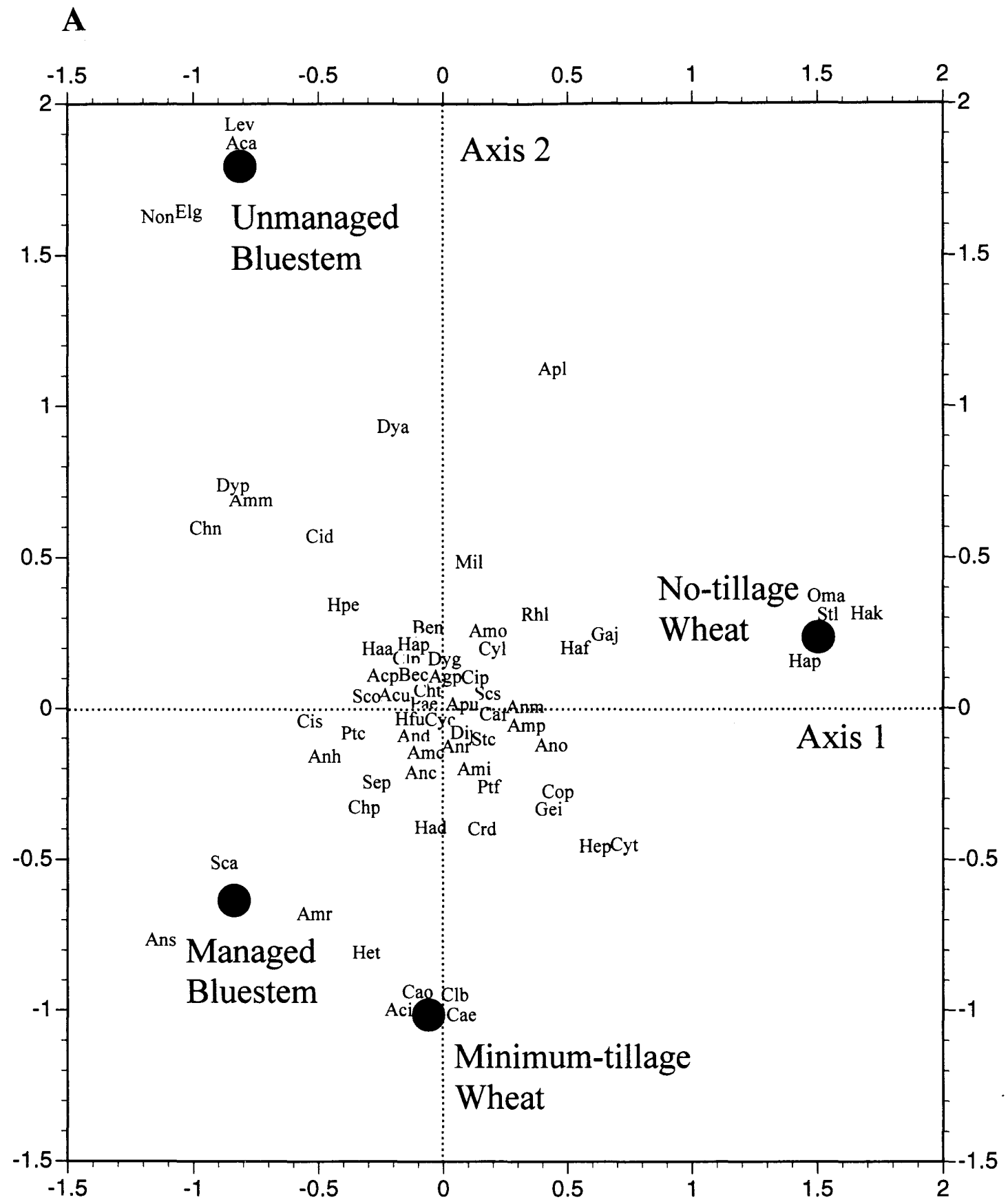

Fig. 4. (A) Biplot of species scores and Conservation Reserve Program reversion strategies (depicted as centroids) obtained from a partial canonical correspondence analysis. Year and month were treated as covariables. Axis 1 ( $\mathrm{x}$ ) and axis 2 (y) are shown. Species names of abbreviations are in Appendix I.

Other studies have shown mixed preferences by ground beetles in agricultural crops when reduced tillage was employed (Dritschilo and Wanner 1980, Barney and Pass 1986, Cárcamo 1995). Cárcamo (1995) found a higher abundance of ground beetles in conventional-tillage barley than in reduced-tillage barley that was attributable to an unusually high num- ber of 1 species. Conversely, species diversity was higher in reduced-tillage barley than in conventionaltillage barley. In alfalfa, ground beetles were more abundant in reduced tillage than in conventional tillage, yet there were no differences in species diversity (Barney and Pass 1986). This is similar to our findings with ground beetle assemblages, except that here both 


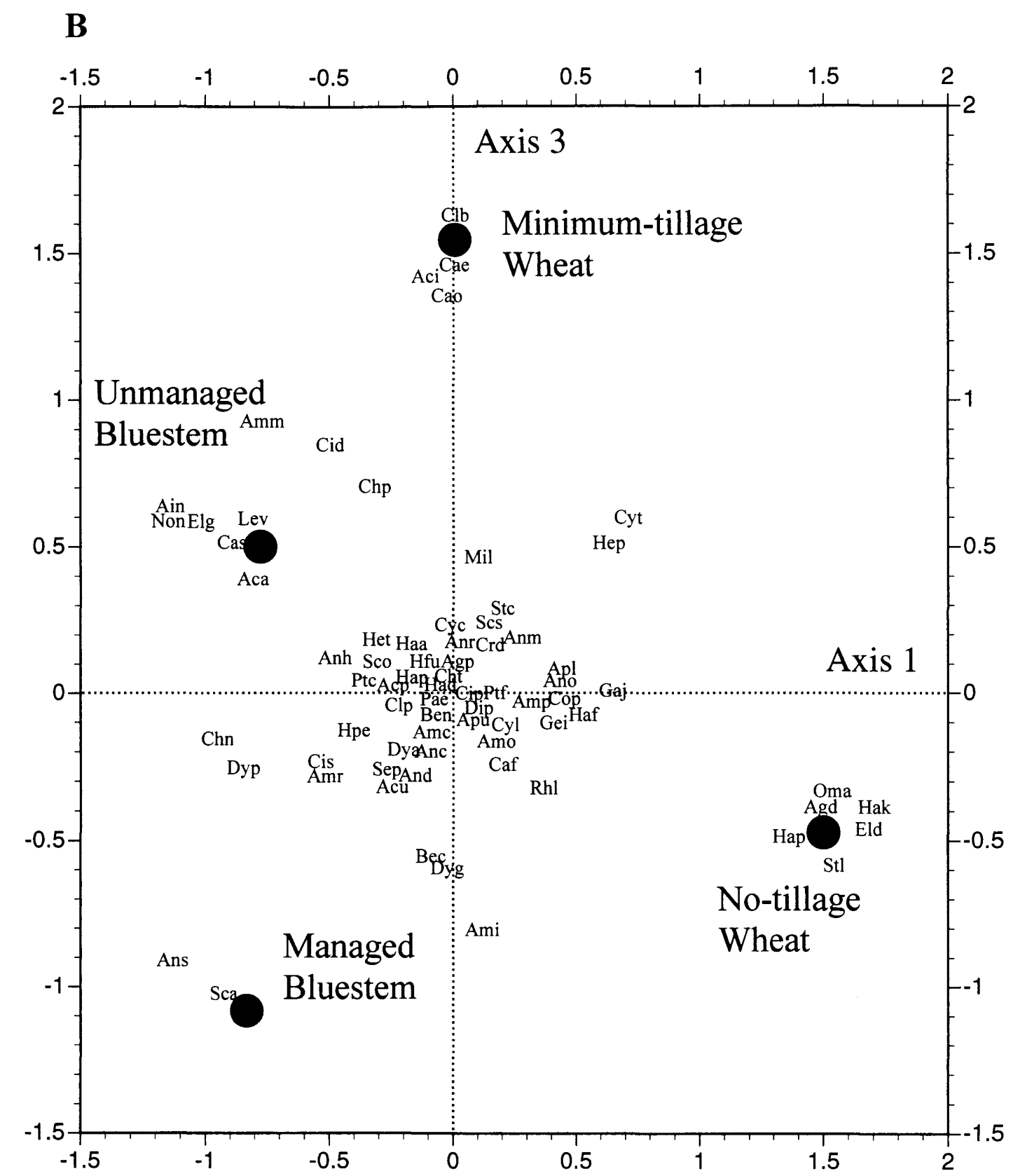

Fig. 4. (B) Biplot of species scores and Conservation Reserve Program reversion strategies (depicted as centroids) obtained from a partial canonical correspondence analysis. Year and month were treated as covariables. Axis $1(\mathrm{x})$ and axis $3(y)$ are shown. Species names of abbreviations are in Appendix 1.

no-tillage and minimum-tillage regimes are conservation practices and species diversity was higher in minimum tillage wheat in 1995, but not in 1996.

Employing no tillage management practices in reverting conservation reserve program lands to wheat production seems more beneficial to ground beetles than employing minimum-tillage management practices. There are several reasons for this. First, notillage wheat strongly ordinated along the lst canon- ical correspondence axis, which explains most of the variation in species scores and therefore is the most important axis (ter Braak 1987, Palmer 1993). Second, total abundance of ground beetles was consistently higher in no-tillage wheat. Third, species richness was consistently higher in no-tillage wheat. Fourth, there was a lower species evenness index in no-tillage wheat, which indicates there are a few species with relatively high abundances. And 5th, there were consistently 


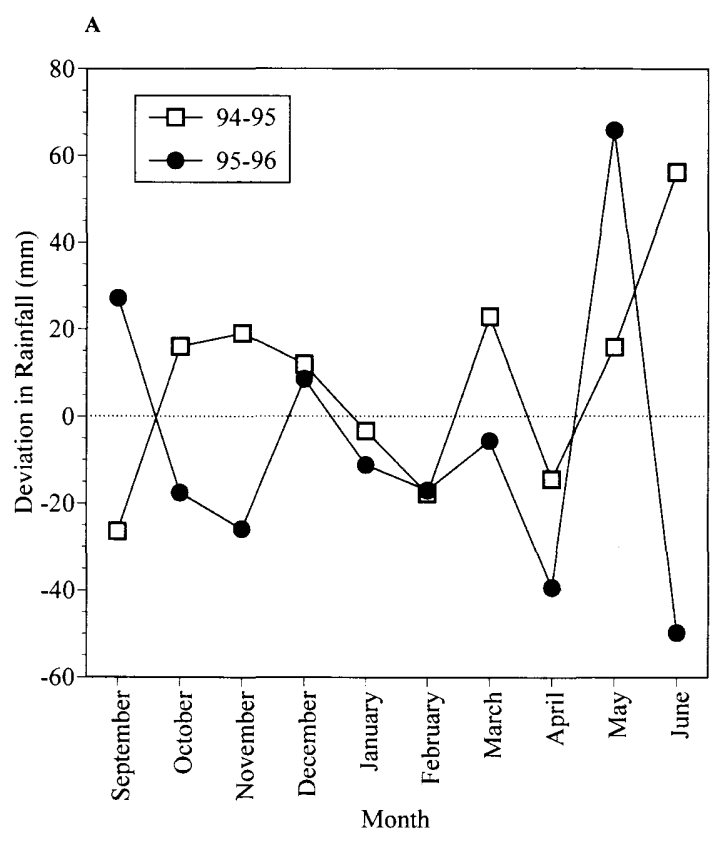

B

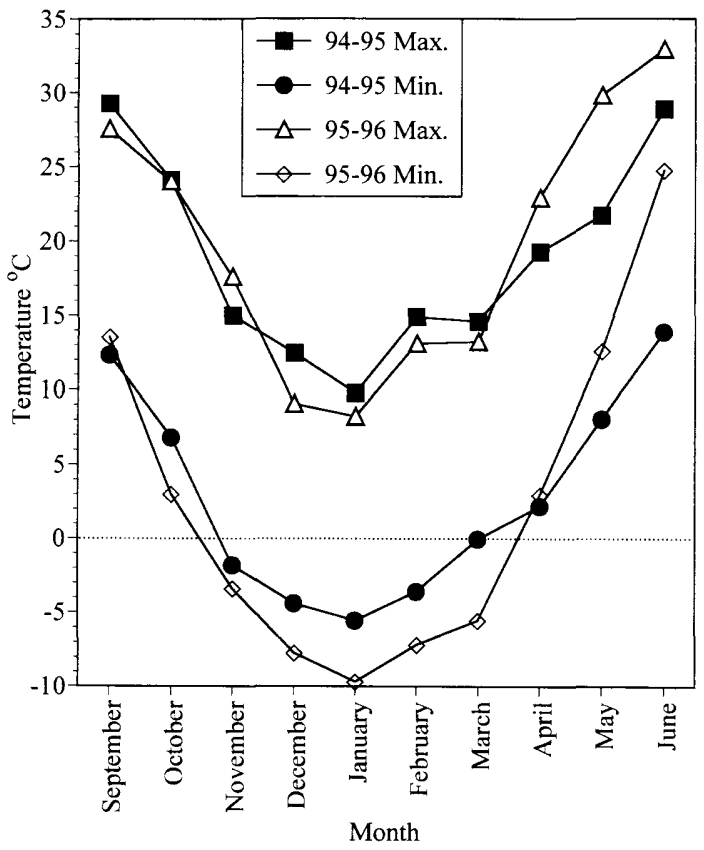

Fig. 5. (A) Monthly deviation of rainfall $(\mathrm{mm})$ from normal amounts. Data obtained from the National Oceanic and Atmospheric Administration (NOAA) for the city of Beaver, OK. The city of Beaver is $\approx 10 \mathrm{~km}$ from the study site. (B) Monthly averages for maximum and minimum temperatures $\left({ }^{\circ} \mathrm{C}\right)$. Data obtained from the NOAA for the city of Beaver, OK.

higher occurrences of rare species in no-tillage wheat. These factors may be related to the level of disturbance each treatment received. The soil in no-tillage wheat is less disturbed than in minimum-tillage.
Ground beetles differed in their response to converting Conservation Reserve Program lands for livestock production. Overall, more ground beetles were captured in managed Old World Bluestem $(1,047)$ than in unmanaged Old World Bluestem (371). This trend was evident in 1995 and 1996 . Other studies have shown mixed preferences by ground beetles for managed and unmanaged grasslands (Luff and Rushton 1988, Morrill 1992, Dennis et al. 1997). Similar to our study, Luff and Rushton (1988) showed that ground beetle diversity was higher in undisturbed grassland and decreased with increasing disturbance. In their study, grazing included the effects of sheep as opposed to the simulated grazing effects reported here. The defecation by sheep could have increased ground beetle diversity and abundance because farmyard manure has been shown to increase ground beetle abundance and diversity in sugar beet plots (Purvis and Curry 1984). In our study, the mowed grass was not removed from the plots and this could have created microhabitats that supported more species and greater abundances (Allen 1979). Dennis et al. (1997) determined that stocking rate, which was directly related to level of disturbance caused by sheep and cattle on upland grasslands, greatly affected ground beetle species and assemblages. Luff and Rushton (1988) also found that disturbance levels affected ground beetle assemblages. Similar to the reasoning with reversion to wheat production, converting conservation reserve program lands to livestock production may be beneficial to ground beetles. Again, there are several reasons for this. First, managed bluestem ordinated closer to the lst canonical correspondence axis than did unmanaged bluestem. Second, total abundance of ground beetles was consistently higher in managed bluestem. Third, species richness was higher in managed bluestem. Fourth, there was a lower species evenness index in managed bluestem, which indicates there are a few species with relatively high abundances. And 5th, there was an overall higher occurrence of rare species in managed bluestem. The ground beetles in our study may have responded to the disturbance level of the soil and vegetation caused by the reversion of Conservation Reserve Program lands to pastures.

Highly erodible lands may be the most difficult lands to manage (Pimentel et al. 1995). These lands are sensitive to natural and human-induced levels of disturbance to the soil and vegetation. For Conservation Reserve Program lands being converted to wheat production, no-tillage production supports higher levels of ground beetles than minimum-tillage. These beetles are known to contribute significantly to the control of agricultural pests, which can reduce the need for applications of pesticides, and increase profits for wheat farmers. Converting Conservation Reserve Program lands to livestock production may enhance ground beetle abundance. Although this study did not use livestock, the simulated grazing effects showed relatively high numbers of ground beetles in the managed Old World Bluestem. Again, the increased numbers of ground beetles may benefit farmers. 


\section{Acknowledgments}

We thank Larry Hodges for the use of his land. Thanh Dao allowed the placement of pitfall traps in his ongoing study, funded by the Southern Region SARE/ACE. Kane Jackson and Tim Johnson helped establish the traps. George Ball and Danny Shpelely identified the ground beetles to species. Lisa Morgan and Kane Jackson helped with species counts. Mike Palmer helped with data analysis. Mike Palmer, Mike Weiss, and James Stiegler reviewed the manuscript. We also thank 2 anonymous reviewers for their comments on the manuscript.

\section{References Cited}

Allen, R. T. 1979. The occurrence and importance of ground beetles in agricultural and surrounding habitats, pp. 485-505. In. T. E. Erwin, G. E. Ball, D. R. Whitehead, and A. L. Halpern [eds.], Carabid beetles: their evolution, natural history, and classification. Junk, The Hague.

Baars, M. A. 1979. Catches in pitfall traps in relation to mean densities of carabid beetles. Oecologia (Berl.) 41: $25-46$.

Barney, R. J., and B. C. Pass. 1986. Ground beetle (Coleoptera: Carabidae) populations in Kentucky alfalfa and influence of tillage. J. Econ. Entomol. 79: 511-517.

Begon, M., J. L. Harper, and C. R. Townsend. 1990. Ecology: individuals, populations and communities. Blackwell, Boston.

Bryan K. M., and S. D. Wratten. 1984. The response of polyphagous predators to prey spatial heterogeneity: aggregation by carabid and staphylinid beetles to their cereal aphid prey. Ecol. Entomol. 9: 251-259.

Cárcamo, H. A. 1995. Effect of tillage on ground beetles (Coleoptera: Carabidae): a farm-scale study in central Alberta. Can. Entomol. 127: 631-639.

Cárcamo, H. A., J. K. Niemelä, and J. R. Spence. 1995. Farming and ground beetles: effects of agronomic practice on populations and community structure. Can. Entomol. 127: 123-140.

Dennis, P., M. R. Young, C. L. Howard, and I. J. Gordon. 1997. The response of epigeal beetles (Col.: Carabidae, Staphylinidae) to varied grazing regimes on upland Nardus stricta grasslands. J. Appl. Ecol. 34: 433-443.

Dritschilo, W., and D. Wanner. 1980. Ground beetle abundance in organic and conventional corn fields. Environ. Entomol. 9: 629-631.

Durkis, T. J., and R. M. Reeves. 1982. Barriers increase efficiency of pitfall traps. Entomol. News 93: 8-12.

Ekbom, B. S., S. Wiktelius, and P. A. Chiverton. 1992. Can polyphagous predators control the bird cherry-oat aphid (Rhopalosiphum padi) in spring cereals? Entomol. Exp. Appl 65: 215-223.

Epstein, M. E., and H. M. Kulman. 1990. Habitat distribution and seasonal occurrence of carabid beetles in eastcentral Minnesota. Am. Midl. Nat. 123: 209-225.

Floate, K. D., J. F. Doane, and C. Gillott. 1990. Carabid predators of the wheat midge (Diptera: Cecidomyiidae) in Saskatchewan. Environ. Entomol. 19: 15031511.

Frampton, G. K., T. Cilgi, G.L.A. Fry, and S. D. Wratten. 1995. Effects of grassy banks on the dispersal of some carabid beetles (Coleoptera: Carabidae) on farmland. Biol. Conserv. 71: 347-355.

French, B. W. 1998. Interactions among assemblages of ground beetles (Coleoptera: Carabidae) in natural and agroecosystems. Ph.D. dissertation, Oklahoma State University, Stillwater.
Gebhardt, M. R., T. C. Daniel, E. E. Schweizer, and R. R. Allmaras. 1985. Conservation tillage. Science (Wash. D.C.) 230: 625-630.

Greenslade, P.J.M. 1964. Pitfall trapping as a method for studying populations of Carabidae (Coleoptera). J. Anim. Ecol. 33: 301-310.

Halsall, N. B., and S. D. Wratten. 1988. The efficiency of pitfall trapping for polyphagous predatory Carabidae. Ecol. Entomol. 13: 293-299.

Holopainen, J. K., and J. Helenius. 1992. Gut contents of ground beetles (Col., Carabidae), and activity of these and other epigeal predators during an outbreak of Rhopalosiphum padi (Hom., Aphididae). Acta Agric. Scand. 42: $57-61$.

Hurlbert, S. H. 1984. Pseudoreplication and the design of ecological field experiments. Ecol. Monogr. 54: 187211.

Kaul, R. B. 1986. Physical and floristic characteristics of the Great Plains, pp. 7-10. Flora of the Great Plains. University of Kansas Press, Lawrence.

Kirk, V. M. 1971. Ground beetles in cropland in South Dakota. Ann. Entomol. Soc. Am. 64: 238-241.

Laub, C. A., and J. M. Luna. 1992. Winter cover crop suppression practices and natural enemies of armyworm (Lepidoptera: Noctuidae) in no-till corn. Environ. Entomol. 21: 41-49.

Luff, M. L., and S. P. Rushton. 1988. The effects of pasture improvement on the ground beetle and spider fauna of upland grasslands. Aspects Appl. Biol. 17: 67-74.

Mauremooto, J. R., S. D. Wratten, S. P. Worner, and G.L.A. Fry. 1995. Permeability of hedgerows to predatory carabid beetles. Agric. Ecosyst. Environ. 52: 141-148.

Morrill, W. L. 1975. Plastic pitfall trap. Environ. Entomol. 4 596.

Morrill, W. L. 1992. Ground beetles (Coleoptera: Carabidae) in Georgia grasslands. J. Agric. Entomol. 9: 179 188.

Morrill, W. L., D. G. Lester, and A. E. Wrona. 1990. Factors affecting efficacy of pitfall traps for beetles (Coleoptera: Carabidae and Tenebrionidae). J. Entomol. Sci. 25: 284 293.

Palmer, M. W. 1993. Putting things in even better order: the advantages of canonical correspondence analysis. Ecology 74: 2215-2230.

Pimentel, D., C. Harvey, P. Resosudarmo, K. Sinclair, D. Kurz, M. McNair, S. Crist, L. Shpritz, L. Fitton, R. Saffouri, and R. Blair. 1995. Environmental and economic costs of soil erosion and conservation benefits. Science (Wash. D.C.) 267: 1117-1123.

Potts, G. R., and G. P. Vickerman. 1974. Studies on the cereal ecosystem. Adv. Ecol. Res. 8: 107-197.

Purvis, G., and J. P. Curry. 1984. The influence of weeds and farmyard manure on the activity of Carabidae and other ground-dwelling arthropods in a sugar beet crop. J. Appl. Ecol. 21: 271-283.

Rushton, S. P., M. D. Eyre, and M. L. Luff. 1986. The effects of management on the occurrence of some carabid species in grassland, pp. 209-216. In N. E. Stork [ed.],The role of ground beetles in ecological and environmental studies. Intercept, Andover, UK

Scheller, H. V. 1984. The role of ground beetles (Carabidae) as predators on early populations of cereal aphids in spring barley. Z. Angew. Entomol. 97: 451-463.

Spence, J. R., and J. K. Niemelä. 1994. Sampling carabid assemblages with pitfall traps: the madness and the method. Can. Entomol. 126: 881-894. 
Stinner, B. J., and G. J. House. 1990. Arthropods and other invertebrates in conservation-tillage agriculture. Annu. Rev. Entomol. 35: 299-318.

Sunderland, K. D., and G. P. Vickerman. 1980. Aphid feeding by some polyphagous predators in relation to aphid density in cereal fields. J. Appl. Ecol. 17: 389-396.

Sunderland, K. D., G. L. Lövei, and J. Fenlon. 1995. Diets and reproductive phenologies of the introduced ground beetles Harpalus affinis and Clivina australasiae (Coleoptera: Carabidae) in New Zealand. Aust. J. Zool. 43: $39-50$.

ter Braak, C.J.F. 1987. CANOCO-a FORTRAN program for canonical community ordination by [partial] [detrended] [canonical] correspondence analysis, principal components analysis and redundancy analysis, version 2.l. Agricultural Mathematics Group, Wageningen.

Thiele, H. U. 1977. Carabid beetles in their environments: a study on habitat selection by adaptations in physiology and behavior. Springer, New York.

Tonhasca, A. Jr. 1993. Carabid beetle assemblage under diversified agroecosystems. Entomol. Exp. Appl. 68: 279 285
Tyler, B.M.J., and C. R. Ellis. 1979. Ground beetles in three tillage plots in Ontario and observations on their importance as predators of the northern corn rootworm, $\mathrm{Di}$ abrotica longicornis (Coleoptera: Chysomelidae). Proc. Entomol. Soc. Ont. 110: 65-73.

[USDA] U.S. Department of Agriculture, Farm Service Agency. 1996. The conservation reserve program. (http://www.fsa.usda.gov/dafp/cepd/12logocv.htm).

[USDA] U. S. Department of Agriculture, Soil Conservation Service and Oklahoma Agricultural Experiment Station. 1962. Soil Survey, Beaver County, Oklahoma. Series 1959, No.11.

Weiss, M. J., E. U. Balsbaugh, Jr., E. W. French, and B. K. Hoag. 1990. Influence of tillage management and cropping system on ground beetle (Coleoptera: Carabidae) fauna in the Northern Great Plains. Environ. Entomol. 19: $1388-1391$.

Winder, L. 1990. Predation of the cereal aphid Sitobion avenae by polyphagous predators on the ground. Ecol. Entomol. 15: 105-110.

Received for publication 1 April 1998; accepted 3 August 1998 
Appendix 1. Species names of abbreviations used in canonical correspondence analysis and partial canonical correspondence analysis biplots

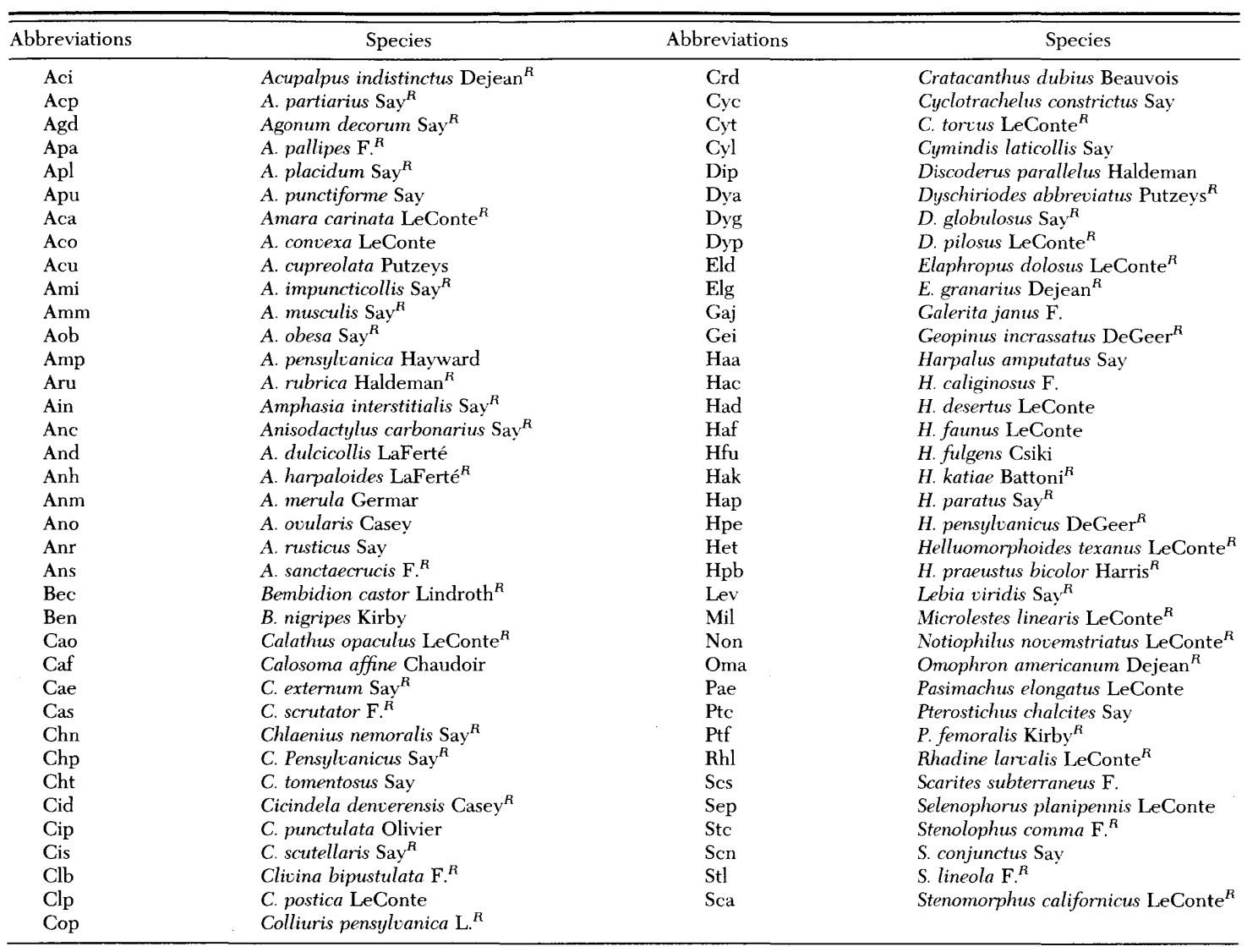

${ }^{R}$, Rare species. 